\title{
SCADA-BASED METHODOLOGY FOR CIRCUIT BREAKER MONITORING AND PROTECTION IN ELECTRICAL DISTRIBUTION NETWORKS
}

\author{
Gamal M. Dousoky ${ }^{1}$, Osama K. Ahmed*2, A. M. El-Sawy ${ }^{3}$ \\ ${ }^{1,2,3}$ Electrical Engineering Department, Faculty of Engineering, Minia University, Minia, Egypt. \\ *Corresponding author Email: eng_osamakhalaf@yahoo.com
}

\begin{abstract}
Supervisory Control and Data Acquisition (SCADA) systems are very necessary to keep up with the modern systems to improve and develop the electrical distribution network and manage it perfectly. The major goal of SCADA is collecting real-time data, controlling equipment and monitoring processes in critical infrastructures and most SCADA systems achieve these functions. Furthermore, in this research the benefit of SCADA system is maximized by other additive functions such as predicting the protection and maintenance procedures of the electrical network components. The circuit breaker is the most important component in the network which must be kept safe and its operation should be carefully monitored. In this paper, the problem of explosion of the expansion chambers in the circuit breaker is discussed and two solutions are suggested to handle this problem by using SCADA system. This research investigates a real existing system and the results of the study is used to enhance the maintenance and operation by monitoring the state of the circuit breaker. The possibility of leakage that may occurs during faults in $\mathrm{SF}_{6} \mathrm{gas}_{\text {is }}$ estimated for remaining its life time. Accordingly, the cost burdens due to fault occurrence will decrease by activating the predictive maintenance.
\end{abstract}

Keywords: Circuit breakers, SCADA, Protection scheme, HMI, RTU, SF ${ }_{6}$ and Electrical distribution networks.

\section{INTRODUCTION}

Currently, there are many technologies available to automate public utility services (such as: distribution and transmission, telecommunication, process monitoring, industrial plant control, power utilities supply, distribution and network monitoring, and renewable resources) $[1,2]$. Supervisory Control and Data Acquisition (SCADA) systems are considered the key technology that support these fields [3-5]. SCADA refers to a system which consists of RTUs (Remote Terminal Units) or PLCs (Programmable Logic Controllers) that collect field data connected back to a master station by a communication system [6], as shown in Figure 1.

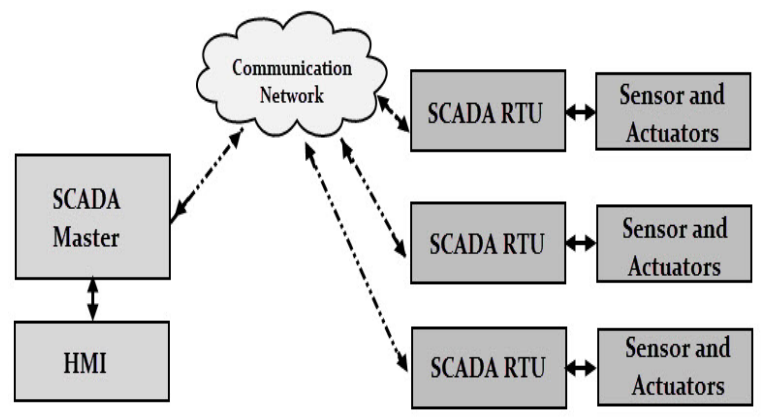

(a) 


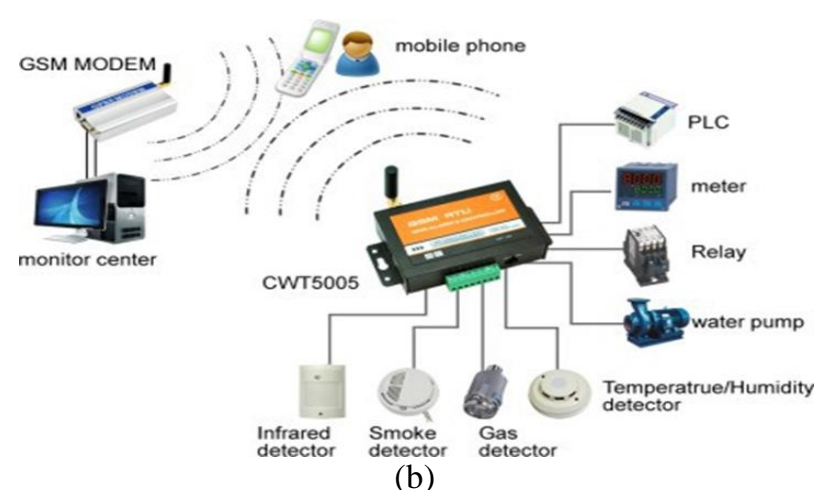

Fig.1. A typical SCADA system: (a) Block diagram, (b) Components.

The spread of electricity networks reflects the progress of countries in different aspects, which are divided into electricity generation, transmission, and distribution networks [7], as shown in Figure 2. It is necessary to employ modern technologies to enhance electricity networks performance, reliability, and feasibility. Nowadays, it is important to monitor, control and collect data from these networks through SCADA systems. Electrical networks consist of poles, wires, electrical cables, insulators, circuit breakers and electrical transformers $[8,9]$. Figure 3 shows some of electrical network components that are monitored by SCADA systems [10].

This paper focuses on the gas $\mathrm{SF}_{6}$ circuit breaker as a dominant component in protection scheme of the electrical network and monitored by SCADA system to achieve better maintenance.

The problem of explosion of expansion chamber in the circuit breaker is solved by estimating the leakage that may occurs in gas during faults. This leads to reduce the cost burdens due to fault occurrence by activating the predictive maintenance effectively.

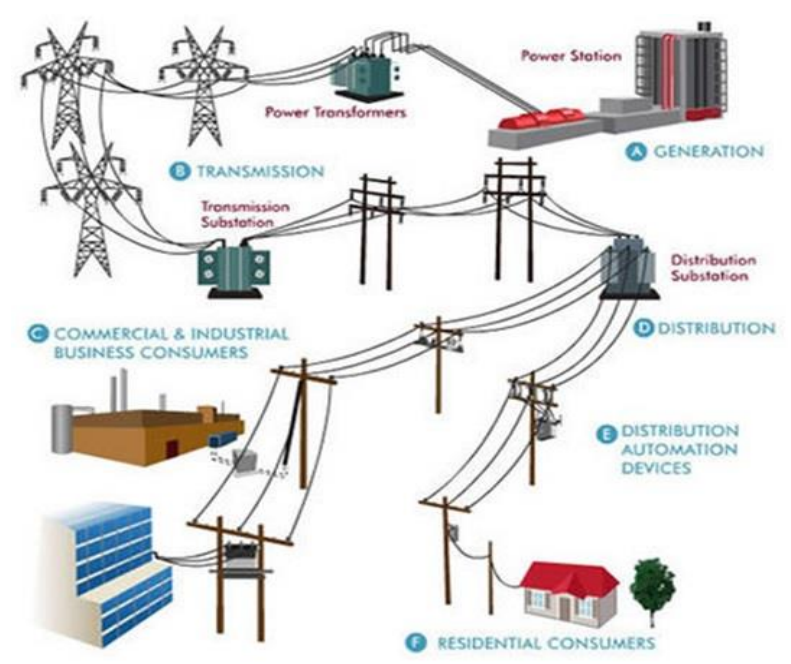

Fig.2. Electricity networks from generation to consumers.
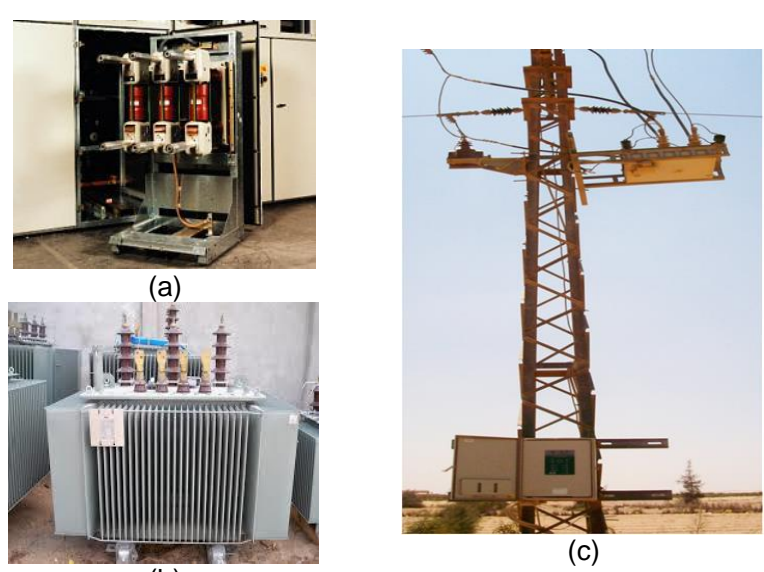

(c)

Fig.3 Electrical distribution network components of interest: (a) Circuit breaker (b) Transformer (c) Automatic recloser.

\section{SCADA SYSTEMS AND THEIR APPLICATION TO ELECTRICAL DISTRIBUTION NETWORKS}

There are some benefits of using SCADA system such as cost effectiveness, overcome the present limitations, efficient usage of new technology [6], controlling and real-time monitoring of large or medium scale systems, in rural or remote areas, high reliability and flexibility. $[4,11,12]$.

The usage of SCADA in electricity distribution networks achieves many outcomes as the follows:

- Control and monitor distribution network continuously can be performed from remote locations [10].

- Save time due to the equipment automatic operation capability.

- Reduce power failure time in distribution network and generate alarms quickly. 
- Increase system reliability.

- Avoid manual data collection burdens.

- Enable operators to detect site problems, solve it quickly and handle automatically.

- Predict future problems and provide better maintenance routine.

- Point out the equipment that needs maintenance and performance improvement.

- Facilitate the view of historian data in various formats.

- Reduce the labor cost such as reducing the staff required for meter reading $[1,11]$.

Previous studies generally addressed SCADA systems and concerned with their communication systems [6], used between SCADA components $[4,12,13]$ and how to secure transferred data between them [10, 14-17].

Other studies discussed the operation theory of SCADA and how to monitor and collect data from electrical distribution electricity components by using PLC or RTU or simple monitoring system [18], especially circuit breakers and transformers [13, 19]. These studies discussed SCADA architectures [6], their provided services and applications $[6,10,12]$, and SCADA application to smart grids [2, 5-7, 20, 21].

This research attains the following unique features:

1. Protecting network components using the

SCADA system and not only to data acquisition and monitor network components only.

2. Post-reporting stage and how different systems could benefit from SCADA applications.

3. It investigates a real existing system and developed it. Furthermore, it deals with the circuit breaker as part of the whole system and not as an independent component and results are integrated with other system components.

4. The research provides a solution to the existing problems and contributes to the organization and quality of the maintenance and operation of the electrical distribution network.

\section{Circuit Breaker Case Study}

The circuit breaker (CB) is responsible of automatically running/stopping income cells and outcome cells [19]. CB depends on protection relay signal due to automatic faults or manual signal from circuit breaker in normal cases such as maintenance and new installations [10]. One of the most important features of $\mathrm{CB}$ is the disconnection on the load or the fault duo to the spark that occurs during the disconnection [7]. Accordingly, the expansion chamber is considered as the most important component in CB. In Figure 4 and Figure 5, show the gas $\mathrm{SF}_{6}$ circuit breaker which is discussed in the paper. Furthermore, the spark occurs in the breaker is the big obstacle in its operation. It produces an electric arc that makes the circuit still connected $[8,9]$. It is known that the life time of these chambers depends on the number of disconnection times. Vendors have different specifications about this life time according to number of automatic/manual disconnection times.

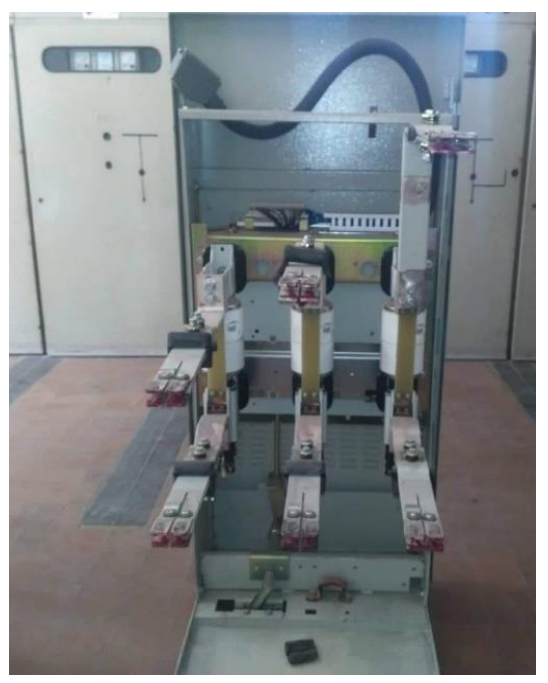

Fig.4. The circuit breaker (SF6). 


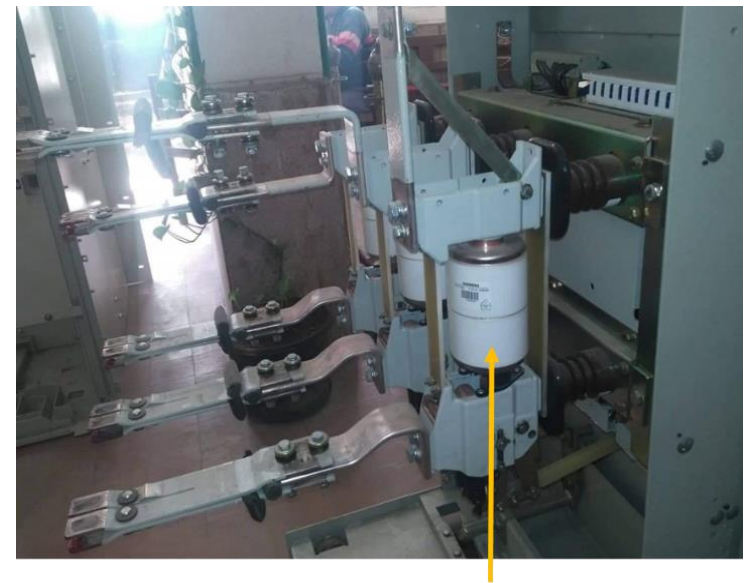

The expansion chamber

Fig.5. The expansion chamber of circuit breaker

\section{Currently Conventional METHODOLOGY}

CONVENTIONALLY, THERE IS A MANUAL COUNTER WITH EVERY CIRCUIT BREAKER FOR COUNTING NUMBER OF DISCONNECTION TIMES AS SHOWN IN FIGURE 6. HOWEVER, THIS COUNTER HAS THE FOLLOWING DRAWBACKS:

- Easy to damage.

- Ability to modify the count and manipulation.

- Inability to differentiate between manual and automatic disconnections.

Accordingly, the state of expansion chambers (good/damaged) can't be certainly estimated. Moreover, its resistance must be measured and its efficiency must be tested during the maintenance. Hence, this is not practical to detect the damage before occurring explosion.
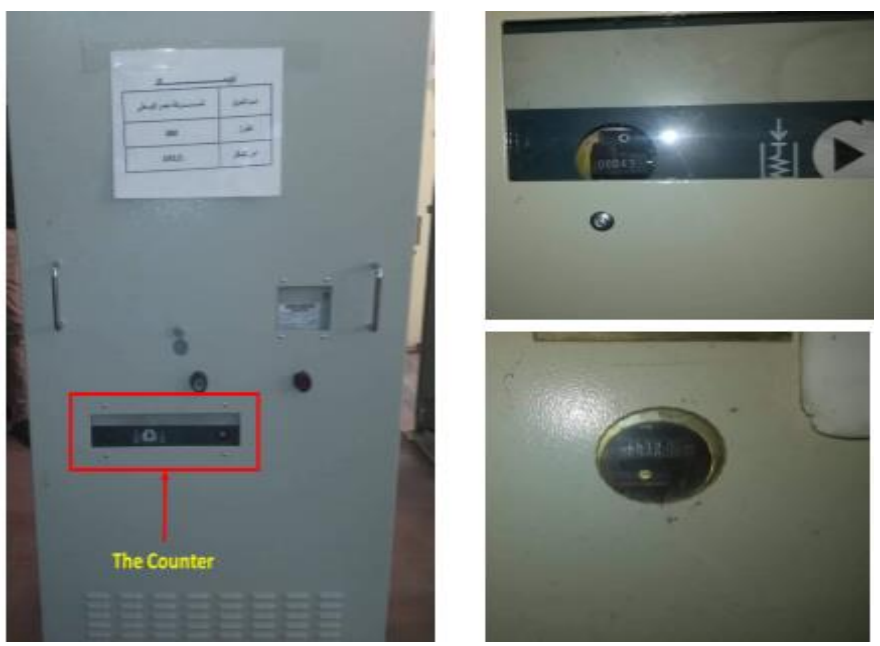

Fig.6. Conventional manual counter

\section{EFFECTS OF THE EXPANSION CHAMBERS EXPLOSION}

The occurring of circuit breaker explosion causes several harmful effects as shown in Figure 7.

\section{Reasons of Expansion Chambers Explosion:}

Many reasons lie behind the expansion chambers explosion, including the following:

1) Exceeding the limit of allowed number of disconnection times according to lifetime, set by manufacturers.

2) Easy to scratch or damage.

3) Gas leaks in the $\mathrm{SF}_{6}$ circuit breaker (Sulfur hexafluoride gas).
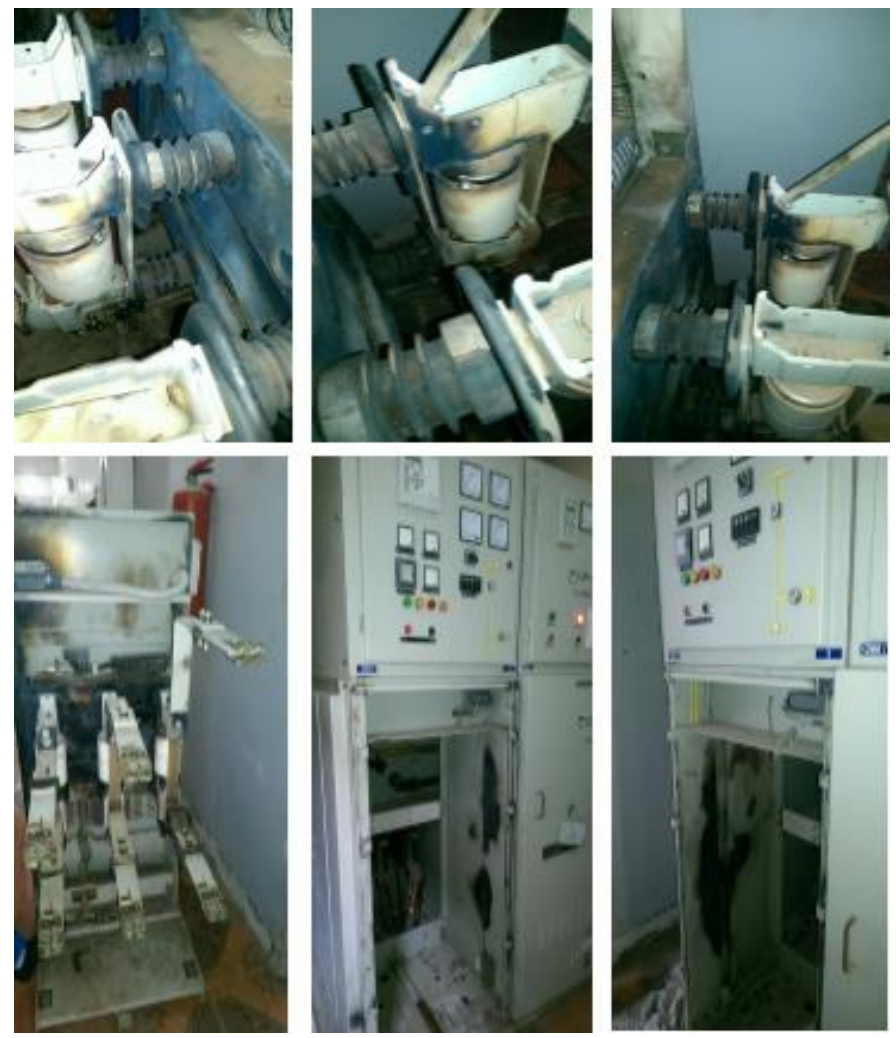

Fig.7. Explosion of the Expansion Chambers Effects

Procedures to Estimate the Possibility of the Expansion Chambers Explosion:

1) Recording the number of disconnection times and differentiating between the manual disconnection and automatic disconnection.

2) Communicating with the sensor in the Expansion Chamber to detect any leakage in gas. 
3) Making periodic maintenance and testing.

\section{Proposed Solutions:}

1) Counting number of manual/automatic disconnection times and reporting it by SCADA system.

2) Recording the report of maintenance and tests operations into SCADA system and making alarm when data is not proper.

3) Communicating with the sensor where the expansion chamber exists and making alarm when the gas leaks.

\section{Proposed Methodology}

Movicon software is used to operate and develop SCADA project of the electricity distribution company (MEEDCO). SCADA system is developed to count number of disconnection times with differentiating between electrical faults and manual disconnections. After every time period, a detailed report is generated to obtain every disconnection signal, and its type and its duration. When the lifetime of the circuit breaker becomes close to end, an alarm signal is generated and reported including number of disconnection times in a report.

\subsection{Differentiating Between Manual Disconnection and Automatic Disconnection:}

In the current situation, the electrical fault disconnections (such as Earth Fault (EF), Overcurrent (OC), ...etc.) are obtained from communicating with the protection relay and the state of circuit breaker (open/close) is obtained from communicating with free contacts in the circuit breaker. When an electrical disconnection occurs in the circuit breaker, SCADA system will integrate with the two different signals to know the type of disconnection and make alarms that will be in alarms page.

In Electrical distribution network, there are three operating states for any circuit breaker, these states are:

1. Normal Close.

2. Normal Open.
3. Open with Fault.

These previous states appear as symbolic figures in SCADA HMI (Human-Machine Interface) as shown in Figure 8.

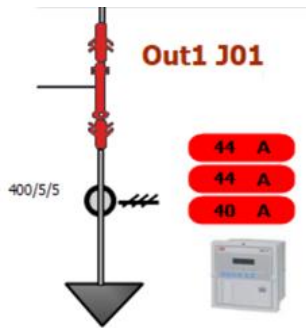

(a)

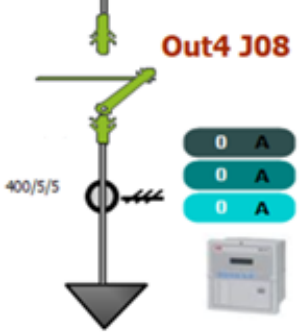

(b)
Fig. 8. symbolic figures of circuit breaker. (a) close state. (b) (Normal/Fault) open state.

In order to know the type of the disconnection and the type of fault, protection relay symbol should be clicked as shown in Figure 9.

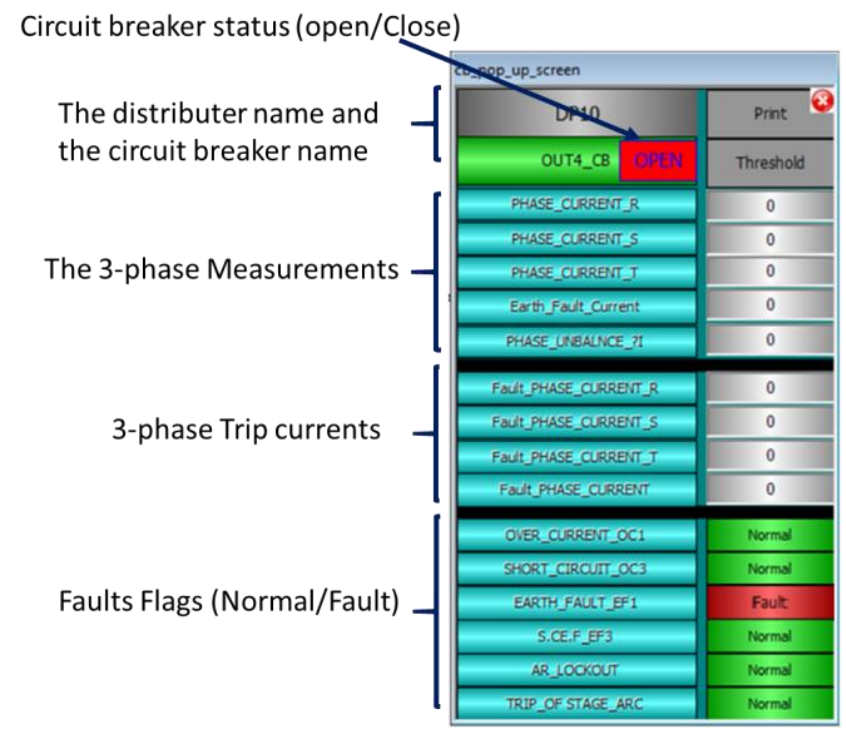

Fig.9. Protection relay screen (pop-up window)

It is clear from the figure 8 and figure 8 that there is a match between the normal open state and the opening with fault state in the current system because:

1. The circuit breaker symbol is one in both cases and cannot differentiation between the two cases.

2. In protection relay screen, there is a great similarity between the two cases. The only difference between them is the fault flag in the place allocated to the fault flags as illustrated in Figure 9. 
3. Operators cannot differentiate between the two cases only after opening the protection relay screen and looking at the fault flags, or going to the alarms screen and events screen to see the type of disconnection, after making sure to activate the feature of the type of fault.

For there, that need emerged to develop the main SCADA screens and the alarms and events screen to determine the status of the circuit breaker directly and to know the type of disconnection and the type of fault directly.

A prototype project is established to verify the proposed concepts. The project screen consists of several objects as shown in Figure 10. The main screen addresses following objects:

a. The most recent alarm appears in the title of the screen.

b. The illustrated keys simulate real fault signals or manual disconnection signal.

c. The circuit breaker symbol in close/open mode.

d. The circuit breaker state in text box where its state is written such as (Normal Close, Normal Open, Open with OC1, Open with OC3, Open with EF1, Open with EF3).

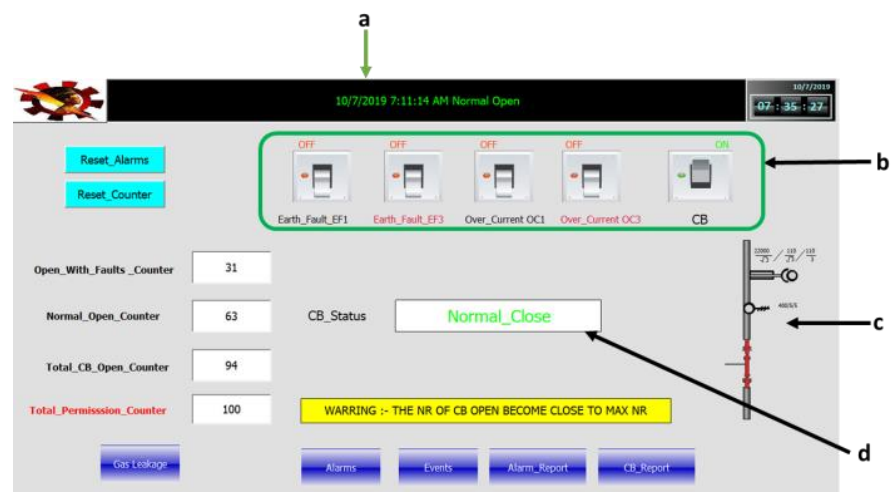

Fig. 10. Prototype project screen.

\subsection{Counting Number of Manual/Automatic Disconnection Times:}

In this prototype, there are 3 counters to count number of disconnection times, number of automatic disconnection times (open with fault) and total number of disconnection times in the circuit breaker as shown in Fig 11 and Fig 12.

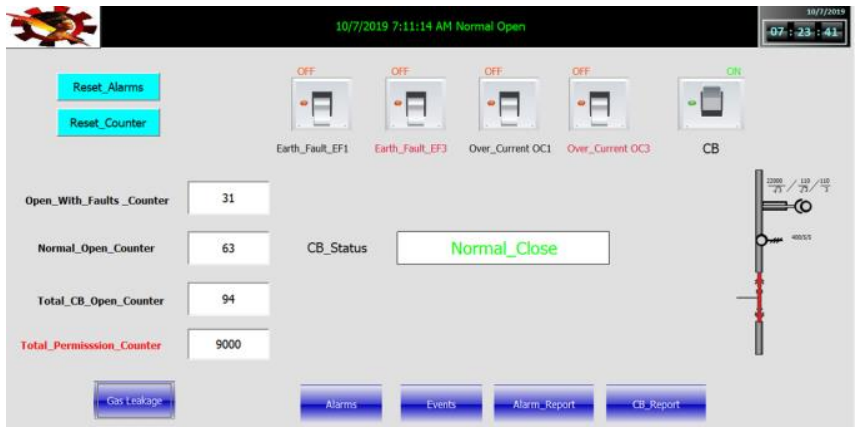

Figure 11. Prototype project screen.

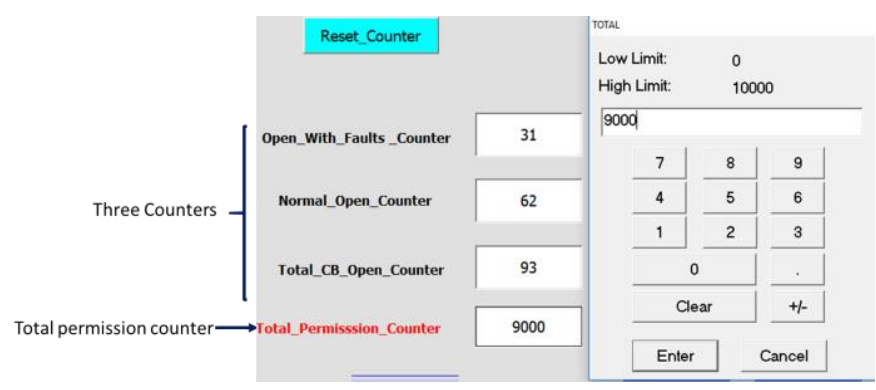

Figure 12. The counters and total permission counter.

In Fig 6, the allowable limit of number of disconnection times in the circuit breaker value can be entered. In Figure 13 of the developed project, yellow warning will appear before exceeding the allowable limit of number of disconnection times in the circuit breaker, and red warning will appear after exceeding the allowable limit. Furthermore, Figure 15 shows the generated analytical report.

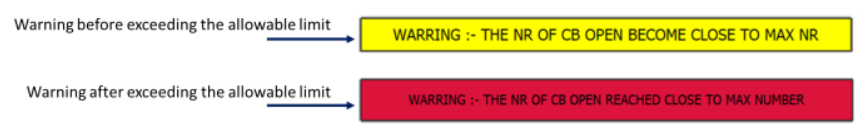

Fig.13. The warning messages.

In Figure 14, an asking message will appear when CB report button is clicked in order to present the time and the date.

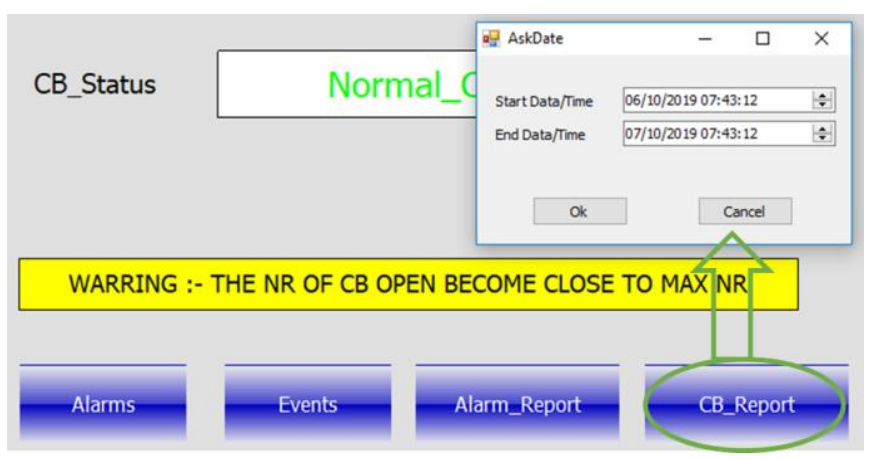

Fig.14. the asking message 


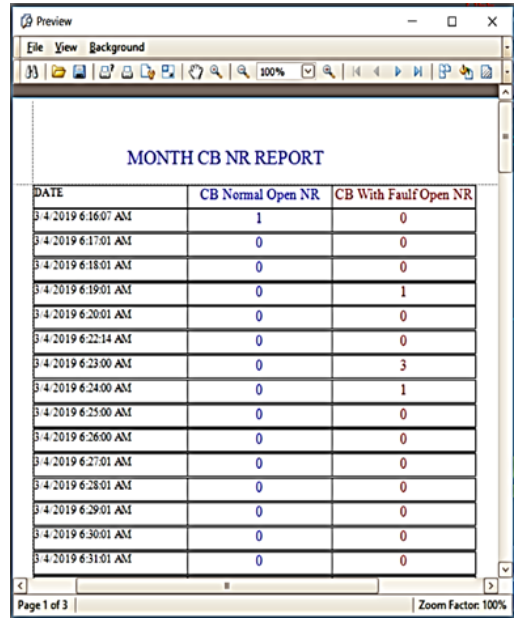

Fig.15. Generated analytical report.

\subsection{Communicating with the Gas Leakage Sensor:}

The gas density of the insulating gas $\mathrm{SF}_{6}$ is continuously monitored by the gas density sensor. This sensor responds reliably to any decreases in the density and pressure of the $\mathrm{SF}_{6}$ insulating gas as shown in Figure 16.

The sensor consists of the following principal components:
a. Aluminum housing and pressure connector.
b. Electronic PCB (Printed Circuit Board) with up to five microswitches.
c. Reference gas bellow, filled with SF6 gas.

The sensor works as following steps:

a. It monitors gas density by way of a reference chamber filled with SF6 gas. The gas and reference chambers are separated by a metal bellows.

b. A density and pressure difference between the two chambers deflect the metal bellows.

c. The movement of the bellows is transmitted by a switch rod.
d. A switch plate activates the microswitches whose purpose is to indicate a pressure drop.

e. When any leakage occurs, SCADA system will send an alarm signal and record it in the analytical report.

Accordingly, the expansion chambers are kept away of the explosion in terms of gas leakage. Hence, maintenance procedures become more effective and predictable.

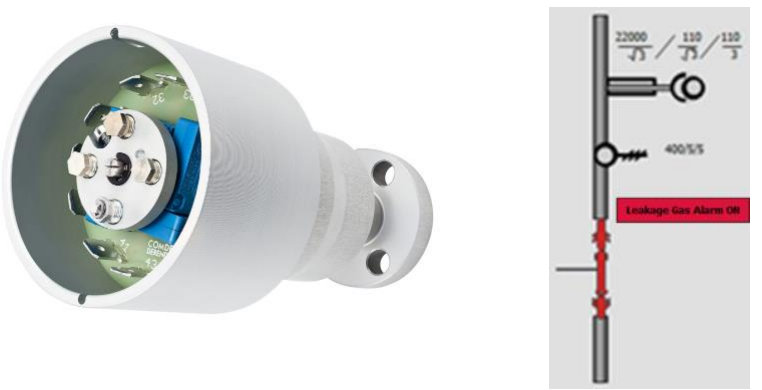

(a)

(b)

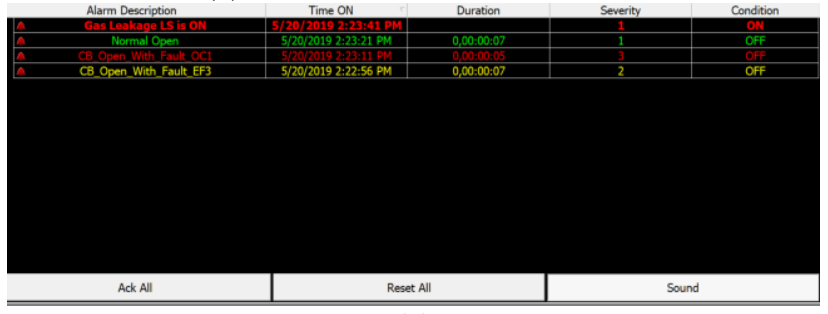

(c)

Fig.16. (a)The gas density monitor (b) its notification in SCADA HMI (c) the alarms page

\section{ConClusion}

This research helps to enable protecting the components of electrical network by using SCADA software. The study confirmed that SCADA system has other multiple uses such as improving the performance of equipment and maintenance procedures inside the electrical network. It is recommended to do other researches to further maximize the benefit of SCADA software and concern with other electrical components such as transformers and automatic voltage regulator. The problem of explosion of the expansion chambers in the circuit breaker is solved by two methods: Firstly, adding counter in SCADA software to track the lifetime of these chambers and making alarm before approaching its end; Secondly, putting sensor in the expansion chamber to detect any leakage in gas and making alarm if any leakage occurs.

Moreover, it is recommended to conduct maintenance procedures with full consideration of SCADA reports and alarms, which participate in predict maintenance effectively.

\section{References}

[1] H. A. M. Abumeteir, "A Proposed SCADA System to improve the conditions of the Electricity sector in Gaza Strip," A Proposed 
SCADA System to improve the conditions of the Electricity sector in Gaza Strip, 2012.

[2] S. A. Boyer, SCADA: supervisory control and data acquisition: International Society of Automation, 2009.

[3] Y. Zhang, L. Wang, Y. Xiang, and C.-W. Ten, "Power system reliability evaluation with SCADA cybersecurity considerations," IEEE Transactions on Smart Grid, vol. 6, pp. 17071721, 2015.

[4] M. B. Mollah and S. S. Islam, "Towards IEEE 802.22 based SCADA system for future distributed system," presented at the 2012 International Conference on Informatics, Electronics \& Vision (ICIEV), 2012.

[5] A. A. Sallam and O. P. Malik, Electric distribution systems: Wiley-IEEE Press, 2018.

[6] M. S. Thomas and J. D. McDonald, Power system SCADA and smart grids: CRC press, 2015.

[7] J. Gers, Distribution system analysis and automation: IET, 2013.

[8] H. E. Lakervi E, Electricity distribution network design, 2nd Edition ed.: The Institution of Engineering and Technology, 1995.

[9] J. M. Gers and E. J. Holmes, Protection of electricity distribution networks vol. 47: IET, 2005.

[10] J. Northcote-Green and R. G. Wilson, Control and automation of electrical power distribution systems: CRC Press, 2006.

[11] S. S. RL Chen, "The Benefits of Implementing Distribution Automation and System Monitoring in the Open Electricity Market," presented at the Canadian Conference on Electrical and Compuler Engineering, Toronto, 2001.

[12] R. H. McClanahan, "The benefits of networked SCADA systems utilizing IPenabled networks," presented at the 2002 Rural Electric Power Conference. Papers Presented at the 46th Annual Conference (Cat. No. 02CH37360), Colorado Springs, CO, USA, 2002.

[13] A. I. P. S. K. Snehal S Maskare, AISSMS IOIT; Susmita S Pendse, AISSMS IOIT; Mr. V. S. Kamble "GSM Based Plc-Scada Burner Control System," IJSRD - International Journal for Scientific Research \& Development, vol. 3, pp. 930-932, 2015.
[14] R. Radvanovsky and J. Brodsky, Handbook of SCADA/control systems security: CRC Press, 2013.

[15] A. Bradley, "Application Guide," SCADA System. Publication AG-6.5, vol. 8, 1998.

[16] W. T. Shaw, Cybersecurity for SCADA systems: Pennwell books, 2006.

[17] S. Chakraborty, "Verification of security intelligence for a resilient SCADA system," 2013.

[18] N. Ved, "Circuit breaker monitoring application using wireless communication," Texas A\&M University, 2007.

[19] M. Knezev, Z. Djekic, and M. Kezunovic, "Automated circuit breaker monitoring," presented at the 2007 IEEE Power Engineering Society General Meeting, 2007.

[20] Q. T. Tran and Y. Besanger, "SCADA as a service approach for interoperability of micro-grid platforms," Sustainable Energy, Grids and Networks, vol. 8, pp. 26-36, 2016.

[21] S. Li, B. Jiang, X. Wang, and L. Dong, "Research and Application of a SCADA System for a Microgrid," Technologies Journal, vol. 5, p. 12, 2017. 
Vol. 39, No. 1. January 2020

\section{منهجية معتمدة على نظام التحكم الإشرافي وتحصيل البيانات (SCADA) لمر اقبة ووقاية قو اطع التيار في شبكات توزيع الكهرباء}

يهدف نظام SCADA إلى جمع ونقل الييانات و التحكم بالعملية الإنتاجية أو الصناعية ومر اقتبها عن بعد بو اسطة شبكة تتحكم بمساحة جغر افية كبيرة وذلك عن طريق تجميع البيانات من المو اقع المختلفة بالثبكة و إرسالها إلى الحاسب الرئيسي لغرض التهائ

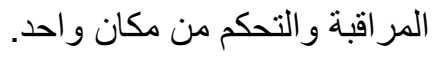

وتعتبرشبكات التوزيع الكهربائية من أهم المجالات التي تستخدم فيها أنظمة SCADA بحيث تتم مر اقبة المعدات وتجميع البيانات عن الثبكة ومن ثم التحكم في الثبكة وذلك في الأنظمة المتقمة من SCADA. ولقد أصبح من الضروري لمو اكبة التطور التكنولوجي ولمعاصرة الأنظمة الحديثة الاستفادة من SCADA في تحسين وتطوير أداء الثبكات الكهربائية وحمايتها و إدارتها بطريقة غير تقليدية.

وتقوم أغلب بر امج SCADA التقليدية على جمع البيانات ومر اقبة المعدات. وفي هذا البحث تم تقديم صورة غير تقليدية للاستفادة من أنظمة SCADA في إدارة وتحسين أداء شبكات التوزيع وحماية مكوناتها.

ويعتبر قاطع خلايا دو ائر الدخول ومغذيات الخروج من أهم مكونات شبكات التوزيع التي ينبخي الحفاظ عليها ومتابعة أدائها.

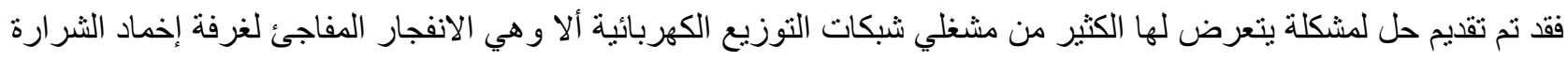

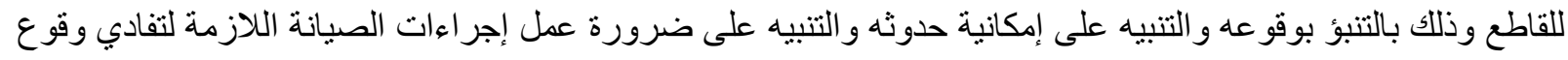
الانفجار ،وذلك من خلال برنامج SCADA.

كما قدم البحث تطوير اً لبرنامج SCADA المستخدم والقائم بحيث يسهل على مشغلي البرامج سرعة التعرف على حالة القو اطع وبيان الأعطال ونو عها. ولقد أُجري هذا البحث على مشروع قائم، وقابل للتطبيق الفوري ـ كما يمكن استخدام نتائجه في تحسين

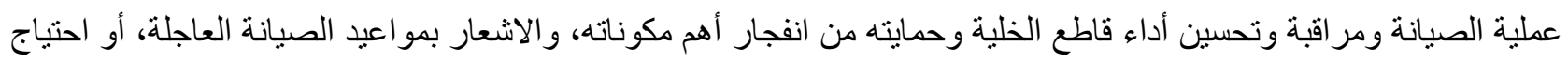

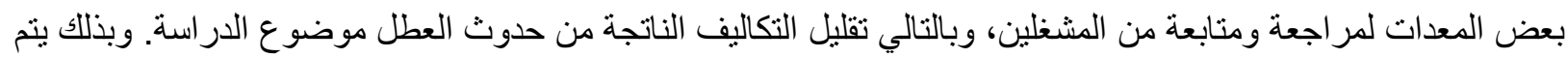
الحفاظ على المعدات و الأيدي العاملة ونوفير تكاليف أعباء الصيانة. 